JOURNAL OF ETHNOBIOLOGY

AND ETHNOMEDICINE

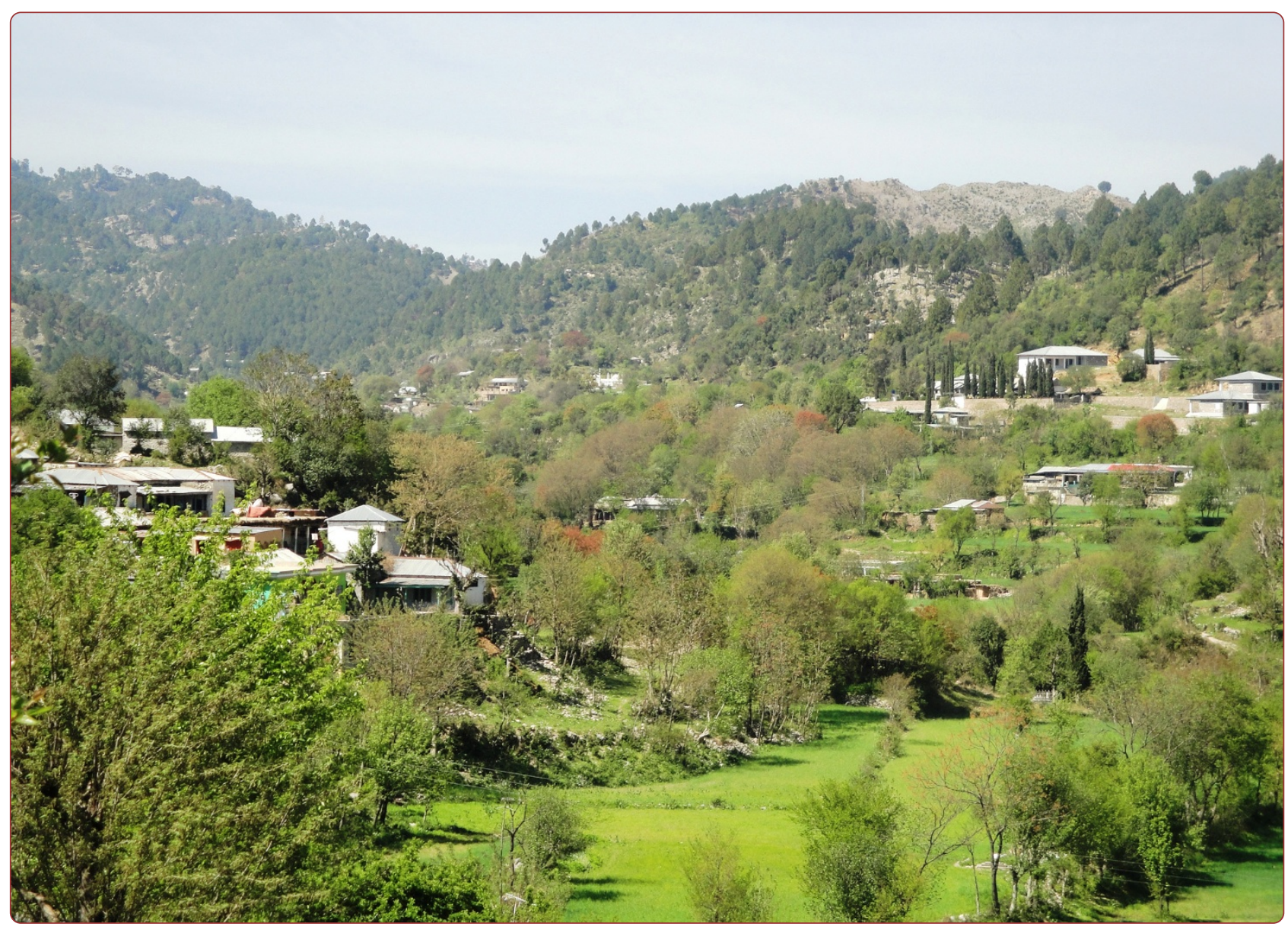

\title{
Botanical ethnoveterinary therapies in three districts of the Lesser Himalayas of Pakistan
}

Abbasi et al. 


\title{
Botanical ethnoveterinary therapies in three districts of the Lesser Himalayas of Pakistan
}

\author{
Arshad Mehmood Abbasi ${ }^{1 *}$, Shujaul Mulk Khan², Mushtaq Ahmad ${ }^{3}$, Mir Ajab Khan ${ }^{3}$, Cassandra Leah Quave ${ }^{4,5}$ \\ and Andrea Pieroni ${ }^{6}$
}

\begin{abstract}
Background: Ethnoveterinary knowledge is highly significant for persistence of traditional community-based approaches to veterinary care. This is of particular importance in the context of developing and emerging countries, where animal health (that of livestock, especially) is crucial to local economies and food security. The current survey documents the traditional veterinary uses of medicinal plants in the Lesser Himalayas-Pakistan.
\end{abstract}

Methods: Data were collected through interviews, focus groups, participant observation, and by administering questionnaires. A total of 105 informants aged between 20-75 years old who were familiar with livestock health issues (i.e. farmers, shepherds, housewives and herbalists) participated in the study.

Results: A total of 89 botanical taxa, belonging to 46 families, were reported to have ethnoveterinary applications. The most quoted families were Poaceae (6 taxa), Fabaceae (6), Asteraceae (5), and Polygonaceae (5). Adhatoda vasica was the most cited species (43\%), followed by Trachyspermum ammi (37\%), and Zanthoxylum armatum var. armatum (36\%). About 126 medications were recorded against more than 50 veterinary conditions grouped into seven categories. The highest cultural index values were recorded for Trachyspermum ammi, Curcuma longa, Melia azedarach, Zanthoxylum armatum var. armatum and Adhatoda vasica. The highest informant consensus factor was found for pathologies related to respiratory and reproductive disorders. Comparison with the local plant-based remedies used in human folk medicine revealed that many of remedies were used in similar ways in local human phytotherapy. Comparison with other field surveys conducted in surrounding areas demonstrated that approximately one-half of the recorded plants uses are novel to the ethnoveterinary literature of the Himalayas.

Conclusion: The current survey shows a remarkable resilience of ethnoveterinary botanical knowledge in the study area. Most of the species reported for ethnoveterinary applications are wild and under threat. Thus, not only is it imperative to conserve traditional local knowledge of folk veterinary therapies for bio-cultural conservation motives, but also to assist with in-situ and ex-situ environmental conservation initiatives, which are urgently needed. Future studies that focus on the validation of efficacy of these ethnoveterinary remedies can help to substantiate emic concepts regarding the management of animal health care and for rural development programs.

Keywords: Medicinal plants, Ethnobotany, Ethnoveterinary, Lesser Himalayas, Pakistan

\section{Introduction}

Ethnoveterinary medicine is a broad field encompassing people's beliefs, skills, knowledge and practices related to veterinary health care [1]. Medicinal plants traditionally used in the treatment of animal diseases play a crucial role in local health modalities. Specifically, phytotherapeutics

\footnotetext{
* Correspondence: amabbasi@ciit.net.pk

'Department of Environmental Sciences, COMSATS Institute of Information Technology, Abbottabad 22060, Pakistan

Full list of author information is available at the end of the article
}

often represent the primary form of therapy in rural veterinary care as allopathic modalities remain inaccessible, especially in the developing world [2]. Therefore, local knowledge of ecological resources for veterinary care is of particular importance to pastoral and agro-pastoral communities that rely heavily on livestock for their livelihood and food security. However, traditional ethnoveterinary knowledge is still mainly orally transmitted from generation to generation (i.e., in the form of traditional remedies, poems, drawings stories, folk myths, proverbs and 
songs). Due to the nature of oral transmission, this form of local knowledge remains fragile and threatened, and presents an urgent need for being recorded and documented.

An increasing number of studies have very recently focused on the documentation of local ethnoveterinary practices in South Asia [3-24]. These studies hold potential for having a tremendous impact on the Himalayan region, in particular, where efforts for sustaining endogenous development and ultimately improving the health and well-being of both animals and humans is still largely neglected. Pakistan has a very large livestock population composed of a number of local breeds that are well adapted to local conditions. In particular, there are an estimated 27 million buffaloes, 30 million cattle, 27 million sheep, 54 million goats, one million camels, 0.3 million horses, 4 million asses, 0.2 million mules and 74 million poultry in Pakistan [25].

The objectives of this field study were multifold: 1 . to record the local knowledge related to medicinal plants used for treating animal diseases in the Lesser Himalayan region in Pakistan; 2. to compare the collected data with the traditional medical knowledge devoted to humans in the same region; 3. to compare the collected data with those of other ethnoveterinary studies conducted in the Himalayan region over the last decades; 4. to assess their cultural importance and the consensus among the informants regarding cited veterinary pathologies; and 5. to examine local perceptions of factors that threaten wild medicinal plant resources.

\section{Materials and methods}

\section{Study site}

An ethnobotanical study was conducted from March 2010 to April 2013 in different locations of the Lesser Himalayas, which is a hotspot for plant biodiversity in Pakistan. Fifty-five localities in three districts (Haripur, Abbottabad and Mansehra) within the Khyber Pakhtunkhwa (KPK) province were selected for inclusion in the study (Figure 1). The Lesser Himalayan range in Pakistan lies between $33^{\circ}-44^{\prime}$ and $35^{\circ}-35^{\prime}$ north latitude and between $72^{\circ}-33^{\prime}$ and $74^{\circ}-05^{\prime}$ east longitude, comprising an area of $23,295 \mathrm{~km}^{2}$. The climate of the area is subtropical in the lowland plains and foot-hills zone and subtropical-sub alpine in middle Himalayas, Siwalik, Murree and entire Hazara hills. The average rainfall varies from $70-90 \mathrm{~mm}$ in southern and $100-130 \mathrm{~mm}$ in the northern parts. The vegetation of the Lesser Himalayas falls within the subtropical, temperate, sub-alpine and alpine zones. The region is divided into six vegetation zones, namely: the subtropical sub-humid zone, the subtropical humid zone, the temperate humid zone, the sub alpine zone and the zone of the glaciers/snowfields. This area is populated by several ethnic groups (Syed, Abbasi, Karaal, Jadoon, Tanoli, Ghakar, Gujar, and Awan), all speaking the
Hindko dialect of the Western Punjabi, and belonging in turn to the Indo-Aryan (Indic) language family spoken in Northern Pakistan.

\section{Ethnobotanical data collection}

Ethnobotanical surveys were conducted in all four seasons. Participatory rural appraisal (PRA) approaches were adopted during fieldwork and prior informed consent was obtained before conducting interviews. Information regarding ethnoveterinary practices was collected through semistructured interviews and guided fieldtrips with the help of traditional healers. A total of 105 informants $(75$ males and 30 females), ranging from $20-75$ years old and including farmers, shepherds, housewives and herbalists familiar with livestock problems and use of conventional recipes, were interviewed and their responses recorded in detail.

Information regarding the vernacular plant names, part (s) used, methods of preparation, mode/route of application and treated diseases were documented during each interview. Taxonomic identification of the collected plant samples was carried out with the help of Flora of Pakistan [26], The Plant List [27] and by one of the authors (MAK, plant taxonomist). Family nomenclature follows the Angiosperm Phylogeny Group III designations [28]. Additionally, 15 key informants were selected at four locations within three study districts (Haripur, Abbottabad and Mansehra) and specific information regarding the perceived threats for the local medicinal flora was obtained. Following identification of 5 key perceived threats (agricultural land expansion, overharvesting, overgrazing, fuel, fire), we employed pair-wise ranking techniques in which respondents were presented with two threats and chose one from the two threats at a time [29]. Respondent scores were then summed up and ranks for each threat determined by region.

\section{Data analysis}

Cultural importance index $(\mathrm{CI})$ values for each species and mean cultural importance values for each family (mCIf) were calculated as described in a previous quantitative ethnobotanical work [30]. Briefly, CI values of species were calculated based on previously described methods [31] and express the sum of the proportion of informants that mention each species used. The CI values for each species were calculated using the following formula, with $\mathrm{UR}_{\mathrm{i}}$ : use reports in each use-category and $\mathrm{N}$ : total number of survey participants:

$$
C I=\sum \frac{U R_{i}}{N}
$$

Moreover, we calculated the mean cultural importance $(\mathrm{mCI})$ index of plant species as measured in three study districts (Haripur, Abbottabad, Mansehra) within the Khyber Pkahtunkhaw Province of Pakistan, on the basis 


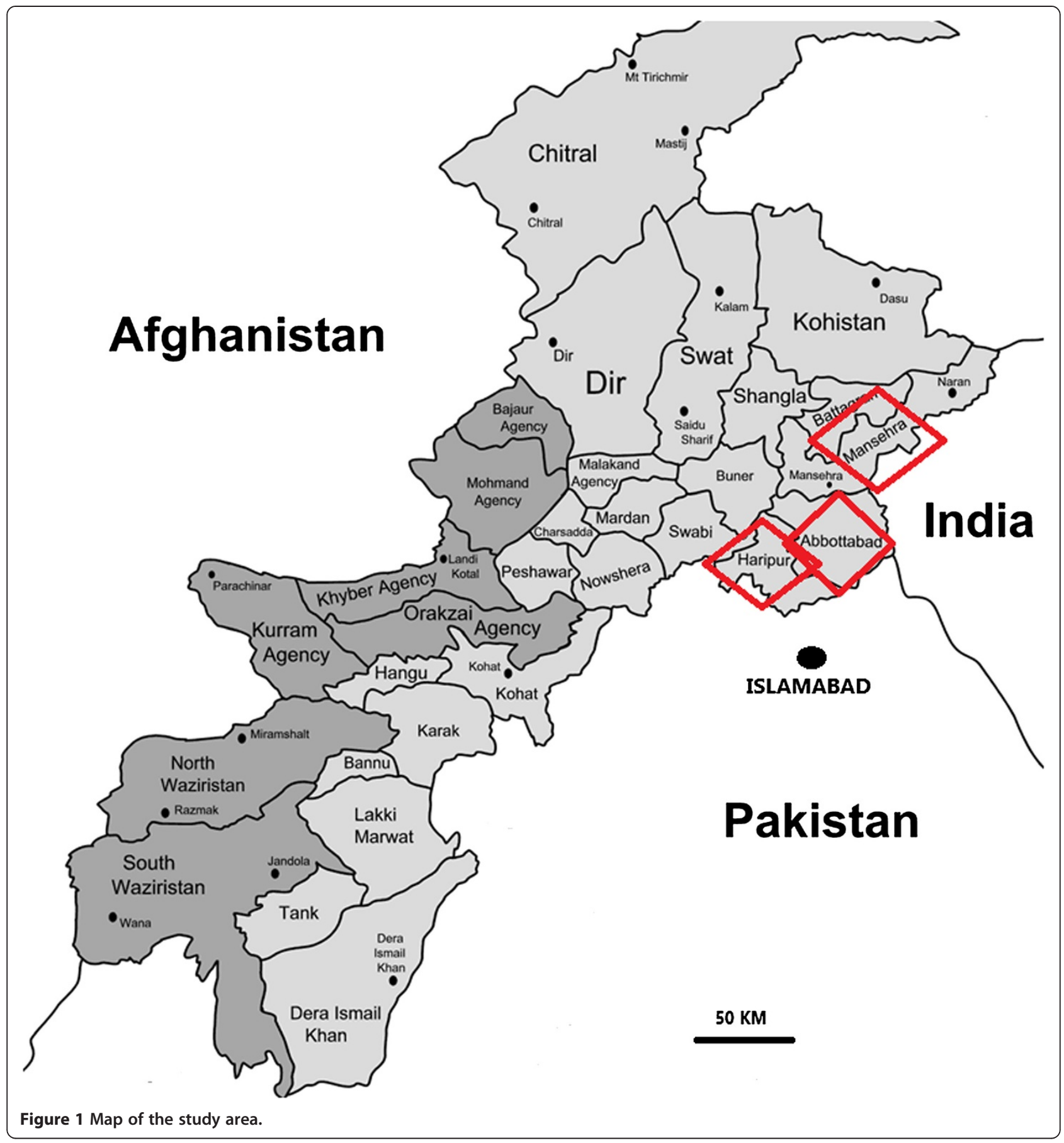

of their cultural importance index (CI) calculated for each single district. To calculate the mCIf, CI values of all reported species within a family were added. Regression analysis was performed upon comparison of mCIf with the number of species in each respective family.

Informant consensus on the reported cures for a given group of aliments was calculated as an informant consensus factor (ICF) [32]. All of the quoted veterinary diseases were grouped into seven categories, which included: gastrointestinal disorders, skin infections, parasites/worms, fever/cold/respiratory diseases, reproductive disorders, musculoskeletal disorders and galactagogue remedies. As previously reported [32], we used the following formula, with $n_{u}$ : number of use citations in each category and $n_{t}$ : number of species used:

$$
I C F=\frac{n_{u r}-n_{t}}{n_{u r}-1}
$$


Table 1 Botanical ethnoveterinary therapies for treating livestock in communities of the Lesser Himalayas in Pakistan

Botanical name and

Local name $\mathrm{PU}^{\mathrm{a}}$ Preparation and application

Veterinary condition

$\mathrm{AT}^{\mathrm{b}}$

$\mathrm{C}^{\mathrm{c}} \mathrm{mCl}^{\mathrm{d}} \mathrm{FR}^{\mathrm{e}} \mathrm{SU}^{\mathrm{f}}$

number

Adhatoda vasica Nees

Bhekker

L

$\mathrm{CIITH}-2$

$1 \mathrm{~kg}$ fresh leaves each of Adhatoda vasica and Stomach disorder, fever, dehydration B,

Rhazya stricta are soaked in water over night

and liquid is orally administered for 3-4 days.

$1 \mathrm{~kg}$ leaves are mixed with grass or husk and fed to animal for 2-3 days.

$1 / 2 \mathrm{~kg}$ each of leaves of Adhatoda vasica and

bulbs of Allium cepa are crushed and paste is

$B, C, G, S h$

fed to animal for 3-4 days.

$1 / 2 \mathrm{~kg}$ fresh leaves are crushed along with table Diarrhea, dysentery, gas trouble _ A, B, C, G, Sh, Cam

salt and resulting paste is fed to animal for

5-6 days.

\section{AMARANTHACEAE}

Aerva javanica (Burm. f.) Juss.

Wp $1 \mathrm{~kg}$ roots are boiled in water and decoction is given orally twice a day for $7-8$ days.

Skin infection

is orally administered at night for 2-3 days.

Amaranthus viridis $\mathrm{L}$.

CIITH-10

Chenopodium album $\mathrm{L}$.

CIITH-25

\section{AMARYLLIDACEAE}

Allium cepa L.

$\mathrm{CIITH}-7$

p $1 \mathrm{~kg}$ fresh plant is crushed and mixed in wheat husk; paste is fed to animal twice a day for 10-15 days.

L L Leaves are boiled in mustard oil, and then crushed and topically applied to wounds.

\section{Intestinal worms}

Against weakness

Wound healing

B, C, G, Sh

$0.276+-$

$A, B, C, H, M$

A, C, Cam, G, M

$30.648-+$

$B, C, G, H, S h$

$30.014-+$

Galactagogue

B, C

paste is mixed with milk and orally

paste is mixed with mik and orally to 1 week.

$1 / 2 \mathrm{~kg}$ of each leaves of Adhatoda vasica and bulbs of Allium cepa are crushed and this paste is orally administered for 3-4 days.

$1 / 2 \mathrm{~kg}$ bulbs are crushed along with salt and mixed in flour. This paste is administered

orally for 4-5 days.

Allium jacquemontii Kunth

$100 \mathrm{~g}$ fresh bulbs are ground and mixed with wheat flour. This paste is applied topically for 10-15 days.

\section{Indigestion}

B, C, G, H, Cam, Sh,

Stomach disorder, fever

$B, C, G$,

Unequal mammary glands

\section{ANACARDIACEAE}

Mangifera indica $\mathrm{L}$.

Pickled fruit is fed to animal for 4-5 days.

Mouth infection

CIITH-51 
Table 1 Botanical ethnoveterinary therapies for treating livestock in communities of the Lesser Himalayas in Pakistan (Continued)

\section{APIACEAE \\ Anethum sowa Roxb. ex Fleming} CIITH-11

Foeniculum vulgare Mill.

CIITH-46

Trachyspermum ammi (L.) Sprague CIITH-79

\section{APOCYNACEAE}

Calotropis procera (Aiton) W.T. Aiton

CIITH-19

Carissa opaca Stapf ex Haines

CIITH-23

Periploca aphylla Decne.

CIITH-57

Rhazya stricta Decne.

CIITH-65

Soay
$100 \mathrm{~g}$ seeds are mixed in wheat flour and orally administered for up to 15-20 days.

$100 \mathrm{~g}$ each of Anethum sowa, Trachyspermum ammi and Foeniculum vulgare are ground together and paste is orally administered for 2-3 days.

Ap $\quad 200 \mathrm{~g}$ of aerial parts are boiled in water. The decoction is mixed with Trachyspermum ammi, Camelia sinensis, brown sugar and ghee. This paste is fed to the animal for 5-6 days.

$200 \mathrm{~g}$ each of Foeniculum vulgare aerial parts and Punica granatum rind are ground together. The resulting powder is orally administered for 4-5 days.

S $\quad 1 / 4 \mathrm{~kg}$ each of Trachyspermum ammi seeds, Anethum sowa, Allium cepa and Foeniculum vulgare are mixed in flour; paste is orally administered to animals for 10-15 days.

L $\quad$ Fresh leaves and black salt are fed to animals for 1-2 days.

St The stem is forcefully administered orally.

Twg Poultice prepared from young twigs is topically applied.

L, S $\quad 1 / 2 \mathrm{~kg}$ fresh leaves and ripened seeds are ground and the resulting powder is mixed in water and orally administered to animals for 2-3 days.

R $\quad 100 \mathrm{~g}$ dried roots are ground into a powder and sprinkled onto wounds for 2-3 days.

$\mathrm{L} \quad$ Fresh leaves are soaked in water and the resulting liquid is orally administered to animals for $8-10$ days.

A decoction of fresh leaves is orally administered for 2-3 days.
Galactagogue

B, C

$51.028+-$

Abdominal pain, swelling

A, C, Cam, G

Indigestion

A, B, C, Cam, H, M

$221.793-+$

Diarrhea

$B, C, G, H S h$

Appetite stimulant, galactagogue$$
\begin{aligned}
& \text { A, B, } \\
& \text { Sh }
\end{aligned}
$$

Mouth and eye watering

C. Cam, G

$150.125-+$

Colic, indigestion

A, C, H, M

Pain, inflammation

C, Cam, H, M

Throat infection

G, Sh

$30.013++$

Infected sores, wound healing

B, C, G, Sh

Skin infection

A, C, Cam, D, H, Sh

$50.213++$

Skin infection and blood purification

$B, C, G, H, S h$

$70.193+$

Abdominal pain

$A, B, C, G, M$ 
Table 1 Botanical ethnoveterinary therapies for treating livestock in communities of the Lesser Himalayas in Pakistan (Continued)

\section{ARACEAE}

Arisaema flavum (Forssk.) Schott

CIITH-12

\section{ARALIACEAE}

Hedera nepalensis K. Koch

\section{CIITH-48}

\section{ASTERACEAE}

\section{Erigeron $\mathrm{sp}$}

CIITH-40

Launaea procumbens (Roxb.)

Ramayya \& Rajagopal

CIITH-49

Saussurea heteromalla (D. Don)

Hand.-Mazz.

CIITH-72

Senecio chrysanthemoides DC

CIITH-73

Tagetes minuta L

CIITH-77

\section{BERBERIDACEAE}

Berberislycium Royle

CIITH-14

\section{BORAGINACEAE}

Cordia obliqua Willd.

CIITH-32

Adbais

8-10 ripened seeds are orally administered.

New Castle disease

P

$20.103-+$

Hurr Bumbal

$200 \mathrm{~g}$ fresh leaves are crushed and soaked in water. The resulting liquid is instilled in the

To remove leeches

nose twice a day for $1-2$ days.

Taku Booti

Doodh Pathar

Kali Zeri

\section{$500 \mathrm{~g}$ of fresh plant material is crushed and} mixed with flour; the paste is orally administered for up to a week.

\section{Paste of fresh leaves is topically applied} for 3-4 days.

Fever, stomach collapse

External worms (skin infection)

Edema

$50 \mathrm{~g}$ seeds are wrapped in paper and animals along with ghee for up to 1 week.

$200 \mathrm{~g}$ dried plant material is ground and the resulting powder is mixed with kneaded flour;

paste is orally administered for 8-10 days.

Chitta Hola

Root decoction is orally administered for 5-6 days.

Paste of fresh plant is topically applied.

Saat Barga

Fresh leaves are soaked in water and the resulting liquid is instilled into the ear

for 2-3 days.

Sumbol

\section{A decoction of $1 / 4 \mathrm{~kg}$ bark is prepared and} orally administered for 10-12 days.

$100 \mathrm{~g}$ bark is ground and powder is sprinkled on wounds up to a week.

Lasoora

2-3 fruits are mixed in fodder and fed for $4-5$ days.

Throat infection, common cold

S Decoction of seeds is administered orally for Stomach ulcer 10-15 days.

Wp Paste of fresh plant is administered orally for a Stomach disorder, intestinal worms
$4 \quad 1.153-$

A, C Cam, G, H

$A, C, D, G, M$

$A, B, C, G, H, M$

C, G, Sh

$80.561+$

C, G, Sh

$B, C, G, S h$ 
Table 1 Botanical ethnoveterinary therapies for treating livestock in communities of the Lesser Himalayas in Pakistan (Continued)

\section{BRASSICACEAE}

Brassica campestris L.

CIITH-17

Eruca sativa Mill.

CIITH-41

\section{CANNABACEAE}

\section{Cannabis sativa L}

CIITH-21

\section{CAPPARACEAE}

Capparis decidua (Forssk.) Edgew.

CIITH-22

\section{CONVOLVULACEAE}

Convolvulus arvensis $L$

CIITH-31

Cuscuta reflexa Roxb.

CIITH-35

\section{CRASSULACEAE}

Bryophyllum pinnatum (Lam.) Oken CIITH-18
Sarain

S $\quad 200 \mathrm{~g}$ seeds are ground with $50 \mathrm{~g}$ of sulfur and mixed with mustard oil. This paste is

topically applied for a week. mixed with eggs and orally administered for 2-3 days.

O 2-3 peppers are soaked in mustard oil for a few days and cooked along with bread, which is fed to animals for 8-10 days.

$200 \mathrm{ml}$ seed oil is mixed with $200 \mathrm{~g}$ of sugar orally administered for $4-5$ days.

\section{Skin infection}

A, B, C, Cam, D, H

$341.359-+$

Stomach disorder/ infection

Eye disease (cornea opacity)

Dysentery

,

$121.176+-$

$B, C, G, H$

B, C, G, Sh

$51.348-+$ applied topically.

$1 / 2 \mathrm{~kg}$ dried leaves are ground and the

Appetite stimulant; abdominal

$B, C, D, G, H, M$ resulting powder is mixed with kneaded flour; swelling the paste is fed is to animals twice a day for a week.

L,Fb, $1 \mathrm{~kg}$ of dried leaves, floral buds and seeds are Indigestion made into a powder and mixed with wheat flour, salt and water. This paste orally administered for 10-15 days.

Ap $\quad 1 / 2 \mathrm{~kg}$ of fresh aerial parts is boiled in water; Stomach gripe, indigestion 1 glass of resulting decoction is orally administered for 5-6 days.

Wp $1 \mathrm{~kg}$ fresh plant is crushed along with sugar and water; this juice is given orally

Constipation for 3-4 days.

Wp $\quad 1 / 2 \mathrm{~kg}$ plant material is crushed and mixed with Galactagogue flour; paste is applied topically for 8-10 days.

Paste of fresh plant is fed to goats and sheep Indigestion for $4-5$ days. 
Table 1 Botanical ethnoveterinary therapies for treating livestock in communities of the Lesser Himalayas in Pakistan (Continued)

\begin{tabular}{|c|c|c|c|c|c|c|c|c|c|}
\hline CUCURBITACEAE & & & & & & & & & \\
\hline $\begin{array}{l}\text { Citrullus colocynthis (L.) Schrad. } \\
\text { CIITH-27 }\end{array}$ & Tumba & $\mathrm{F}$ & $\begin{array}{l}\text { Juice is extracted by heating the fruit of } \\
\text { Citrullus colocynth is and Calotropis procera in } \\
\text { a mud pot on a garbage fire for } 2-3 \text { weeks; it } \\
\text { is orally administered for up to a week. }\end{array}$ & $\begin{array}{l}\text { Indigestion, gas trouble, abdominal } \\
\text { worms }\end{array}$ & $\begin{array}{l}\text { B, C, Cam, D, G, H, M, } \\
\text { Sh }\end{array}$ & 17 & 0.514 & + & - \\
\hline & & & $\begin{array}{l}100 \mathrm{~g} \text { fruit is crushed and mixed in Aloe vera } \\
\text { pulp. This paste is orally administered } \\
\text { for } 2-3 \text { days. }\end{array}$ & Constipation & B, C, Cam, D, Sh & & & & \\
\hline $\begin{array}{l}\text { Citrullus vulgaris Schrad. } \\
\text { CIITH-28 }\end{array}$ & Rainda & $\mathrm{F}$ & $\begin{array}{l}1 \mathrm{~kg} \text { fresh fruit coat is ground with salt and } \\
\text { orally administered for 10-12 days. }\end{array}$ & Appetite stimulant, galactagogue & A, C, Cam, G & 13 & 0.417 & + & - \\
\hline $\begin{array}{l}\text { Cucumis melo L. } \\
\text { CIITH-33 }\end{array}$ & Chibber & $L, F$ & $\begin{array}{l}\text { Paste from fresh leaves and fruits are fed to } \\
\text { animals for up to } 1 \text { week. }\end{array}$ & Indigestion & $\mathrm{B}, \mathrm{C}, \mathrm{G}, \mathrm{Sh}$ & 5 & 0.463 & - & - \\
\hline EUPHORBIACEAE & & & & & & & & & \\
\hline $\begin{array}{l}\text { Euphorbia wallichii Hook. f. } \\
\text { CllTH-43 }\end{array}$ & Hervi & Ltx & $\begin{array}{l}50 \mathrm{ml} \text { stem latex is topically applied } \\
\text { for } 2-3 \text { days. }\end{array}$ & Rashes, wound healing & A, C, Cam, D, G, M & 3 & 0.041 & + & + \\
\hline $\begin{array}{l}\text { Mallotus philippensis (Lam.) Müll. Arg. } \\
\text { CIITH-50 }\end{array}$ & Kamila & $\mathrm{F}$ & $\begin{array}{l}1 / 4 \mathrm{~kg} \text { dried fruits are ground and the resulting } \\
\text { powder is fed to animals along with wheat } \\
\text { flour for } 2-3 \text { days. }\end{array}$ & Intestinal worms & C, G, Sh & 21 & 1.103 & - & + \\
\hline $\begin{array}{l}\text { Ricinus communis L. } \\
\text { CIITH-66 }\end{array}$ & Hernoli & S & $\begin{array}{l}1 / 2 \text { cup of seed oil is orally administered for up } \\
\text { to a week. }\end{array}$ & Constipation & B, C, Cam, G, H, Sh & 8 & 0.052 & - & + \\
\hline FABACEAE & & & & & & & & & \\
\hline $\begin{array}{l}\text { Acacia nilotica (L.) Willd. ex Delile } \\
\text { CIITH-1 }\end{array}$ & Kiker & Bk & $\begin{array}{l}\text { Decoction of } 1 / 2 \mathrm{~kg} \text { bark is orally administered } \\
\text { twice a day for } 5-6 \text { days. }\end{array}$ & Stomach disorder & $\mathrm{B}, \mathrm{C}, \mathrm{H}$ & 10 & 0.686 & - & + \\
\hline $\begin{array}{l}\text { Cassia fistula L. } \\
\text { CIITH-24 }\end{array}$ & Kinjal & S & $\begin{array}{l}4-6 \text { seeds are mixed with chicken feed and } \\
\text { fed to hens. }\end{array}$ & Newcastle disease & $P$ & 3 & 0.413 & - & + \\
\hline $\begin{array}{l}\text { Cicer arietinum L. } \\
\text { CIITH-26 }\end{array}$ & Kalay & S & $\begin{array}{l}200 \mathrm{~g} \text { seeds are ground and resulting powder } \\
\text { is mixed with yogurt; this paste is orally } \\
\text { administered for } 10-15 \text { days. }\end{array}$ & Piles & C & 2 & 0.139 & - & - \\
\hline $\begin{array}{l}\text { Dalbergia sissoo Roxb. ex DC. } \\
\text { CIITH-37 }\end{array}$ & Tahli & L & $\begin{array}{l}1 / 2 \mathrm{~kg} \text { fresh leaves of Dalbergia sissoo and } \\
200 \mathrm{~g} \text { linseeds are boiled in water. This } \\
\text { decoction is administered orally for 8-10 days. }\end{array}$ & Constipation & $C, G$ & 3 & 0.117 & - & + \\
\hline $\begin{array}{l}\text { Phyllodium pulchellum (L.) Desv. } \\
\text { CIITH-39 }\end{array}$ & Ladan & Rt & $\begin{array}{l}\text { Root decoction is administrated orally } \\
\text { for } 10-15 \text { days. }\end{array}$ & Fever, weakness & $A, B, C, H, M$ & 12 & 0.075 & + & + \\
\hline $\begin{array}{l}\text { Trigonella foenum-graecum } \mathrm{L} \text {. } \\
\text { CIITH-82 }\end{array}$ & Mathray & S & $\begin{array}{l}200 \mathrm{~g} \text { seeds are ground and the resulting } \\
\text { powder is used orally after washing urethra } \\
\text { with a sugar and potash alum (potassium } \\
\text { alum) mixture for } 4-5 \text { days. }\end{array}$ & Urethra prolapse & $B, C$ & 13 & 1.541 & - & - \\
\hline & & & $\begin{array}{l}50 \mathrm{~g} \text { seeds are mixed with fodder and fed to } \\
\text { animal for 3-4 days. }\end{array}$ & Diarrhea & $\mathrm{B}, \mathrm{C}$ & & & & \\
\hline
\end{tabular}


Table 1 Botanical ethnoveterinary therapies for treating livestock in communities of the Lesser Himalayas in Pakistan (Continued)

\section{LAMIACEAE}

Ajuga bracteosa Wall. ex Benth.

CIITH-6

\section{LYTHRACEAE}

Punica granatum L.

CIITH-63

\section{MELIACEAE}

Melia azedarach L.

CIITH-52

\section{MORACEAE}

Ficus palmata Forssk

CIITH-45

\section{MYRTACEAE}

Eucalyptus camaldulensis Dehnh.

CIITH-42

Syzygium cumini (L.) Skeels

CIITH-76

\section{NITRARIACEAE}

Peganum harmala $\mathrm{L}$.

CIITH-56
$125 \mathrm{~g}$ shade-dried plant is ground and resulting Abdominal pain powder is mixed with flour and orally

administered for 2-3 days.

Druni

$\mathrm{Fr} \quad 1 / 4 \mathrm{~kg}$ dried rind is ground and the resulting powder is fed to animals along with flour up

Dysentery to 1 week.

Dhrek

$L \quad 200 \mathrm{~g}$ fresh leaves are crushed along with sugar and water; the mixture is administered orally to animals for 2-3 days.

Tw $100 \mathrm{~g}$ fresh twigs are crushed and soaked in water; the resulting liquid is given orally for 2-3 days.

$\mathrm{Fr} \quad 200 \mathrm{~g}$ fruit rinds are soaked in water and the resulting juice is given orally for $4-5$ days.

L,Tw, $200 \mathrm{~g}$ of fresh leaves, twigs and fruits are

F crushed. This paste is fed to animals up to a week.

L, F $\quad 1 / 2 \mathrm{~kg}$ dried leaves and fruits are ground and the resulting powder is administered orally with water for 5-6 days.

Safada

Fresh leaves are fed to animals for 4-5 days.

Common cold

Diarrhea

Mastitis

Hremal

$\mathrm{L}, \mathrm{Br}$ Smoke of leaves and branches is used for 4-5 days.

$L \quad 1 / 2 \mathrm{~kg}$ fresh leaves ground with salt; paste is orally administered for 5-6 days.

S $\quad 200 \mathrm{~g}$ dried seeds are burnt and mixed in mustard oil. This infusion is applied topically 2-3 days.
Foot, mouth infection 
Table 1 Botanical ethnoveterinary therapies for treating livestock in communities of the Lesser Himalayas in Pakistan (Continued)

\section{OLEACEAE}

Olea ferruginea Royle.

CIITH-54

\section{PAPAVERACEAE}

Fumaria indica (Hausskn.) Pugsley

\section{CIITH-47}

\section{PLANTAGINACEAE}

Plantago lanceolata L.

CIITH-58

Plantago major L.

CIITH-59

\section{POACEAE}

Cynodon dactylon (L.) Pers.

CIITH-36

Oryza sativa L.

CIITH-55

Saccharum bengalense Retz.

CIITH-71

Sorghum halepense (L.) Pers.

CIITH-75

Triticum aestivum L.

CIITH-83

Zea mays L

CIITH-88

\section{POLYGONACEAE}

Polygonum amplexicaule D. Don. CIITH-60

Kahu F Extract of fruits is given orally for 5-6 days. Indigestion

C, G

$30.017++$

Papra

Wp Fresh plant material is fed to animals

Diarrhea

C, G

$6 \quad 1.511-+$

for 2-3 days.

Neck rashes

C, Cam, G, H, M

$20.173++$

ChimchipAtra Wp $200 \mathrm{~g}$ dried plant is ground and the resulting Infected hooves powder is sprinkled on infected hooves for 6-7 days.

Khabul Wp $100 \mathrm{~g}$ of fresh plant material is ground and the paste is topically applied for 2-3 days.

Wound healing

$A, B, C, D, H, M$

$7 \quad 0.351-+$

Chawal

$\mathrm{S} \quad 1 \mathrm{~kg}$ rice is boiled in water along with yoghurt Weakness, lung infection and Eruca sativa oil; paste is fed to animals for $15-20$ days.

Kana

Rt $\quad 1 / 2 \mathrm{~kg}$ roots are boiled along with $1 / 2 \mathrm{~kg}$ Solanum surattense; decoction is orally administered for 8-10 days.

Baru

Rt Fresh roots are crushed and soaked in water the resulting liquid is orally administered for 2-3 days.

Kank

S $\quad 200 \mathrm{~g}$ seed porridge is given orally to animals for a week.

Hot bread is fed to cattle for a week.

$1 / 4 \mathrm{~kg}$ seeds are ground with brown sugar and the resulting paste is fed to animal for 8-10 days.

Maki

Stg A decoction of the female inflorescence isorally administered for $4-5$ days.

Mosloon

Root decoction is orally administered to animals for 1 week.

$L \quad$ Fresh leaves are fed to animals for $3-4$ days. 
Table 1 Botanical ethnoveterinary therapies for treating livestock in communities of the Lesser Himalayas in Pakistan (Continued)

\begin{tabular}{|c|c|c|c|c|c|c|c|c|c|}
\hline $\begin{array}{l}\text { Polygonum plebeium } \mathrm{R} \text {. Br. } \\
\text { CIITH-61 }\end{array}$ & Sarwar Booti & $W p$ & $\begin{array}{l}\text { Paste of the fresh plant is applied topically for } \\
2-3 \text { days. }\end{array}$ & Scorpion bite & $B, C, D, H$ & 3 & 0.109 & + & - \\
\hline Rumex dentatus $\mathrm{L}$. & Jngli & Rt & Root decoction is orally administered for up & Foot, mouth infection & C, G, Cam, H, M & 4 & 0.014 & + & + \\
\hline CIITH-68 & Palak & & to a week. & & & & & & \\
\hline Rumex hastatus D. Don & Khitiml & Ap & Arial parts are used as a brush for a week. & Scabies & $B, C$ & 3 & 0.915 & - & + \\
\hline \multicolumn{10}{|l|}{ CIITH-69 } \\
\hline & & Rt & $\begin{array}{l}1 \mathrm{~kg} \text { of each of Rumex hastatus roots and } \\
\text { Quercus incana bark are boiled; decoction is } \\
\text { mixed in sugar and flour. This sweet meal is } \\
\text { fed to animals for } 8-10 \text { days. }\end{array}$ & Cough, fever, weakness & $B, C, G$ & & & & \\
\hline Rumex nepalensis Spreng. & Hoola & L & $\begin{array}{l}\text { Extract of fresh leaves is topically applied to } \\
\text { infected parts for } 4-5 \text { days. }\end{array}$ & Antiseptic and anti-inflammatory & $C, G, M, S h$ & 2 & 0.013 & - & + \\
\hline \multirow{2}{*}{ CIITH-70 } & & & Leaf paste is applied topically for $2-3$ days. & Hemostatic & $A, B, C, D$ & & & & \\
\hline & & Rt & $\begin{array}{l}1 / 2 \mathrm{~kg} \text { fresh roots are crushed with salt and the } \\
\text { resulting paste is administered orally } \\
\text { for } 5-6 \text { days. }\end{array}$ & $\begin{array}{l}\text { Diarrhea, dysentery, and intestinal } \\
\text { worms }\end{array}$ & $\mathrm{G}$, Sh & & & & \\
\hline \multicolumn{10}{|l|}{ PRIMULACEAE } \\
\hline $\begin{array}{l}\text { Myrsine africana } \mathrm{L} \text {. } \\
\mathrm{ClITH}-53\end{array}$ & Khukan & L & $\begin{array}{l}\text { Fresh leaves are fed to animals for up to a } \\
\text { week. }\end{array}$ & Indigestion, worms & $\mathrm{G}, \mathrm{Sh}$ & 17 & 0.735 & + & + \\
\hline \multicolumn{10}{|l|}{ PTDERIDACEAE } \\
\hline $\begin{array}{l}\text { Adiantum incisum Forssk. } \\
\text { CIITH-3 }\end{array}$ & Sarhaaj & L & $\begin{array}{l}\text { Paste of crushed leaves is made by mixing } \\
\text { with wheat flour and orally administered for } \\
2-3 \text { days. }\end{array}$ & Abdominal pain & $B, C$ & 5 & 0.336 & + & + \\
\hline \multicolumn{10}{|l|}{ RANUNCULACEAE } \\
\hline $\begin{array}{l}\text { Clematis grata Wall. } \\
\mathrm{CIITH}-30\end{array}$ & Dhand & L & $\begin{array}{l}\text { Paste of fresh leaves is applied topically on } \\
\text { infection sites. }\end{array}$ & To kill external worms in wounds & A, C, Cam, D, M & 17 & 0.432 & + & + \\
\hline \multicolumn{10}{|l|}{ RHAMNACEAE } \\
\hline $\begin{array}{l}\text { Ziziphus nummularia (Burm. f.) Wight \& Arn. } \\
\text { CIITH-89 }\end{array}$ & Beri & L & $\begin{array}{l}100 \mathrm{~g} \text { leaves are boiled and decoction is orally } \\
\text { administered for } 1-2 \text { days. }\end{array}$ & To discharge placenta following birth & $B, C$ & 7 & 0.018 & - & + \\
\hline \multicolumn{10}{|l|}{ ROSACEAE } \\
\hline \multirow[t]{2}{*}{ CIITH-62 } & Aru & $\mathrm{L}$ & $\begin{array}{l}\text { Juice of fresh leaves is applied topically } \\
\text { for } 4-5 \text { days. }\end{array}$ & To kill germs/worms & $A, B, C, D, H, M$ & 21 & 1.783 & - & + \\
\hline & & & $\begin{array}{l}\text { Leaf decoction is orally administered } \\
\text { for } 2-3 \text { days. }\end{array}$ & Dysentery & G, Sh & & & & \\
\hline Pyrus pashia Buch.-Ham. ex D. Don & Batangi & $\mathrm{F}$ & $\begin{array}{l}\text { Powder of dried fruits is given orally } \\
\text { for } 5-6 \text { days. }\end{array}$ & Dysentery, diarrhea & $\mathrm{B}, \mathrm{C}$ & 4 & 0.241 & - & + \\
\hline
\end{tabular}


Table 1 Botanical ethnoveterinary therapies for treating livestock in communities of the Lesser Himalayas in Pakistan (Continued)

\section{Rosa cymosa Tratt.}

CIITH-67

\section{RUTACEAE}

Citrus limon (L.) Osbeck

CIITH-29

Zanthoxylum armatum var. armatum

CIITH-87

\section{SAPINDACEAE}

Aesculus indica (Wall. ex Cambess.) Hook. Bankhor CIITH-5

\section{SAXIFRAGACEAE}

Bergenia ciliata (Haw.) Sternb.

Batpia

CIITH-15

Bergenia stracheyi (Hook. f. \& Thomson) Batpia Engl.

Batpia

\section{CIITH-16}

\section{SCROPHULARIACEAE}

Verbascum thapsu $S$ L.

\section{CIITH-85}

\section{SOLANACEAE}

\section{Datura innoxia Mill.}

CIITH-38

Solanum surattense Burm. f.

CIITH-74

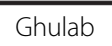

Nimbu

Timer

Datura

Mhokri is fed to animals and applied topically (to the

mammary glands) for 10-15 days.

L $\quad 100 \mathrm{~g}$ leaves are crushed and mixed with kneaded flour; the resulting paste fed to animals for 3-4 days.

$\mathrm{S}, \mathrm{F} \quad 50 \mathrm{~g}$ seeds/fruit are orally administered with flour.

F $\quad 1 / 4 \mathrm{~kg}$ fruits are ground and the powder mixed with husk and fed to animals for 5-6 days.

Fruit juice is applied topically up to a week.

External wounds

Hemostatic (for bleeding wounds)

Rh Fresh leaves are slightly crushed and applied as bandages on bleeding wounds.

Dried rhizome powder is sprinkled onto wounds for 8-10 days.

Rh Dry root powder is sprinkled onto wounds for Wound healing 8-10 days.
Wp $100 \mathrm{~g}$ fresh plant is crushed and paste is fed Diarrhea to animal for a week.

L L Leaf extract is applied topically for 1-2 days.

Wp Fresh fruit paste is applied topically for 2-3 days.

$1 / 2 \mathrm{~kg}$ fresh plant is cooked with salt, peppers and yoghurt. This paste is orally administered for $10-15$ days.
$151.341-+$

$A, B, C, G, D, M$

$A, B, C, G, D, M$

$120.785+$

C, D

$21.135-+$

B, C

$90.543-+$

$B, C, G, D, H, M$

$180.984-+$

B, C, G, H, Sh 
Table 1 Botanical ethnoveterinary therapies for treating livestock in communities of the Lesser Himalayas in Pakistan (Continued)

\begin{tabular}{|c|c|c|c|c|c|c|c|c|c|}
\hline & & & $\begin{array}{l}200 \mathrm{~g} \text { fresh plant is boiled along with black pepper } \\
\text { and salt; decoction is given orally for 8-10 days. }\end{array}$ & Fever, indigestion, cough & $C, G$ & & & & \\
\hline $\begin{array}{l}\text { Withania somnifera (L.) Dunal } \\
\text { CIITH-86 }\end{array}$ & Aksan & Rt & $\begin{array}{l}200 \mathrm{~g} \text { fresh roots are crushed and paste is } \\
\text { applied topically up to a week. }\end{array}$ & Mastitis & $B, C, G$ & 8 & 0.736 & - & + \\
\hline \multicolumn{10}{|l|}{ TAMARICACEAE } \\
\hline $\begin{array}{l}\text { Tamarix aphylla (L.) H. Karst. } \\
\text { CIITH-78 }\end{array}$ & Rokh & L & $\begin{array}{l}\text { An infusion of the dried, burnt leaves is applied } \\
\text { topically onto the skin, nose and ear in livestock. }\end{array}$ & To kill external worms in wounds & $A, C, D, H$ & 5 & 0.011 & + & - \\
\hline \multicolumn{10}{|l|}{ THEACEAE } \\
\hline $\begin{array}{l}\text { Camellia sinensis (L.) Kuntze } \\
\text { CIITH-20 }\end{array}$ & Chay & $L$ & $\begin{array}{l}1 / 2 \mathrm{~kg} \text { fresh leaves are boiled in water along } \\
\text { with sugar; } 1 \text { glass of this decoction is given } \\
\text { orally for } 5-6 \text { days. }\end{array}$ & Fever & $C, G$ & 4 & 0.101 & + & + \\
\hline \multicolumn{10}{|l|}{ VITACEAE } \\
\hline $\begin{array}{l}\text { Vitis vinifera L. } \\
\text { CIITH-84 }\end{array}$ & Dakh & $\begin{array}{l}L_{1} \\
W d\end{array}$ & $\begin{array}{l}\text { Ash prepared from wood and leaves of is } \\
\text { orally administered with milk for } 8-10 \text { days. }\end{array}$ & Hemoglobinuria & $C, G$ & 3 & 0.191 & + & + \\
\hline \multicolumn{10}{|l|}{ XANTHORRHOEACEAE } \\
\hline $\begin{array}{l}\text { Aloe vera (L.) Burm. f. } \\
\text { CIITH-9 }\end{array}$ & Kwar Gandal & L & $\begin{array}{l}1 / 2 \mathrm{~kg} \text { of leaf pulp, salt and Trachyspermum } \\
\text { ammi are mixed and paste is administered } \\
\text { orally for up to } 1 \text { week. }\end{array}$ & Digestive problems & $C, G, H$ & 8 & 0.175 & - & + \\
\hline $\begin{array}{l}\text { Asphodelus tenuifolius Cav. } \\
\text { CIITH-13 }\end{array}$ & Bokhat & L & $\begin{array}{l}\text { Fresh leaves are crushed and fed to horses for } \\
8-10 \text { days. }\end{array}$ & Constipation & A, C, Cam, H & 3 & 0.037 & + & - \\
\hline \multicolumn{10}{|l|}{ ZINGIBERACEAE } \\
\hline $\begin{array}{l}\text { Curcuma longa L. } \\
\text { CIITH-34 }\end{array}$ & Haldi & Rt & $\begin{array}{l}\text { Powder from dried roots is applied and wrapped } \\
\text { or sprinkled onto wounds for } 2-3 \text { days. }\end{array}$ & Wound healing & A, C, Cam, H & 4 & 2.181 & - & - \\
\hline \multicolumn{10}{|l|}{ ZYGOPHYLACEAE } \\
\hline $\begin{array}{l}\text { Fagonia indica Burm. f. } \\
\text { CIITH-44 }\end{array}$ & Dhamian & Wp & Fresh leaves are fed to animals for $8-10$ days. & Appetite stimulant, indigestion & B, C, Cam, G, H & 2 & 0.015 & + & - \\
\hline \multirow[t]{2}{*}{$\begin{array}{l}\text { Tribulus terrestris L. } \\
\text { CIITH-89 }\end{array}$} & Bhakra & L & $\begin{array}{l}200 \mathrm{~g} \text { of each of Tribulus teristri dried leaves, } \\
\text { Curcuma domestica and Foeniculum vulgare are } \\
\text { ground together and the resulting powder is } \\
\text { orally administered to cattle for } 10-15 \text { days. }\end{array}$ & Appetizer, joint pain & B, C, Cam, G, H & 7 & 0.472 & + & + \\
\hline & & & $\begin{array}{l}\text { Paste of fresh plant is orally administered for } \\
\text { up to a week. }\end{array}$ & Gastric problems & $B, C$ & & & & \\
\hline
\end{tabular}

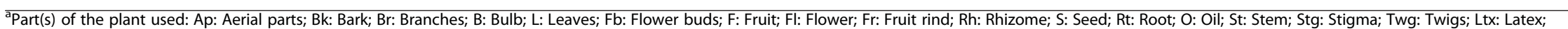
Wd: Wood; Wp: Whole plant.

${ }^{\text {b} A T: ~ A n i m a l s ~ t r e a t e d . ~ A: ~ a s s ; ~ B: ~ b u f f a l o ; ~ C: ~ c o w ; ~ C a m: ~ c a m e l ; ~ D: ~ d o g ; ~ D k: ~ d o n k e y ; ~ G: ~ g o a t ; ~ H: ~ h o r s e ; ~ M: ~ m u l e ; ~ P: ~ p o u l t r y, ~ S h: ~ s h e e p ; ~ S w: ~ s w i n e . ~}$

${ }^{\mathrm{c}} \mathrm{C}$ : Number of citations.

${ }^{d} \mathrm{mCl}$ : mean cultural importance index value.

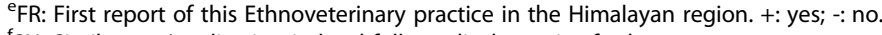

fSU: Similar use/application in local folk medical practice for humans.t: yes; -: no. 


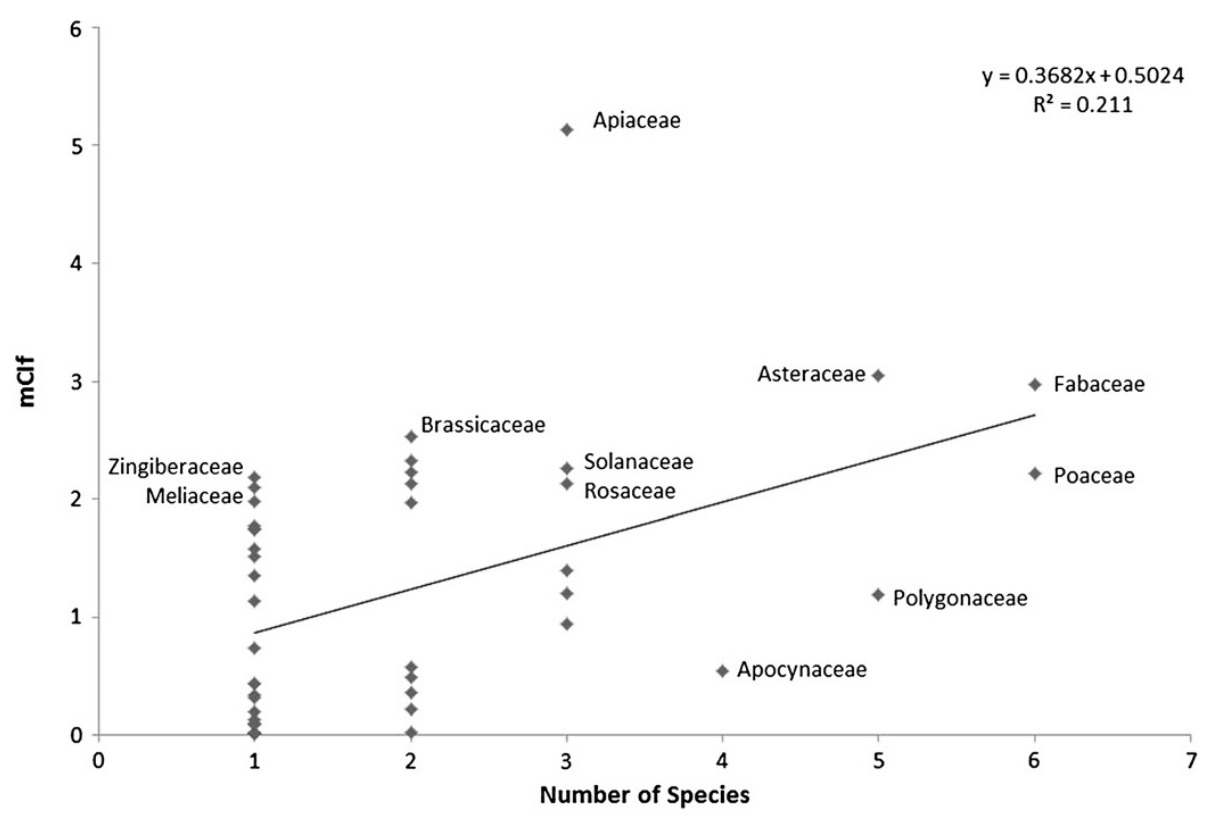

Figure 2 Regression of the cultural importance of the families ( $\mathrm{mClf}$ ) on the number of species in the family.

Lastly, collected data were compared with previously conducted ethnoveterinary studies carried out in surrounding areas $[8,33-45]$.

\section{Result and discussion}

\section{Taxonomic diversity of the species}

A total of 89 plant species belonging 81 genera and 46 families were reported by the study participants against veterinary aliments have been gathered and documented alphabetically along with their local names, parts used, preparations, applications, indications and citation numbers (Table 1). Among the most utilized botanical families, Poaceae and Fabacaeae were ranked first with highest number of species (6 taxa), followed by Asteraceae (5), Polygonaceae (5), and Apocynaceae (4) (Figure 2).

\section{Most versatile and used veterinary plants}

Of the 89 recorded plant species, frequently applied plant species against veterinary ailments included: Adhatoda vasica, Calotropis procera, Melia azedarach, Rumex nepalensis (6 diseases); Cannabis sativa (5); Aesculus indica, Allium cepa, Citrullus colocynthis and Rumex hastatus (4). Adhatoda vasica was the most cited species (43\%), followed by Trachyspermum ammi (37\%), Zanthoxylumarmatum var. armatum (36\%), Allium cepa (33\%), and Brassica campestris (32\%). Based on the diversity of conditions treated by plants in each family, the Polygonaceae family was found to have the broadest application with 8 recipes for the treatment of 17 veterinary conditions $(8 / 17)$, followed by Poaceae (7/10), Asteraceae and Fabaceae (7/7), and Apiaceae and Cucurbitaceae (5/7).
Plant parts used, their preparations and applications

Among the plant parts included in veterinary applications, leaves were most commonly used (26\%), followed by seeds (13\%), whole plant (13\%), and fruits (11\%). The methods of preparation of the therapeutic materials sometimes varied from individual to individual (e.g., the same plant material for the same ailment could be prepared in different ways, depending upon the preferences of different healers). A list of 126 ethnoveterinary remedy preparations is presented in Table 1 . The large majority of recipes being were prepared from single plants (70\%) rather than mixtures. In most cases, water was the solvent employed in preparation of the remedy. Besides plants and water, some other materials were also commonly incorporated in the preparations: salt, sugar, milk, oil, eggs and ghee. The most common therapeutic formulations fall into eleven main categories, the most popular of which were pastes (35\%), fresh plant parts $(15 \%)$, decoctions $(14 \%)$, and powders (13\%).

\section{Ethnoveterinary plant uses}

Study participants identified more than 50 veterinary ailments that could be grouped into seven general categories: gastrointestinal disorders (these were treated by 47 formulations); skin infections (30), parasites, fever and respiratory diseases (10), reproductive disorders (9), lactation (4), and musculoskeletal system disorders (3). More than 40 taxa were documented for their application to treat more than two veterinary conditions.

By comparing the present data with all of the available ethnoveterinary literature concerning the surrounding 
geographic areas, it appears that nearly half of the quoted plants have never been described before as useful in folk veterinary practices. The other half has already been reported in the literature, but in some cases, for different ethnoveterinary purposes. In this section, we explore some reports on other ethnoveterinary applications of these species in the literature. This discussion is organized by plant family.

\section{Acanthaceae}

Regarding Adhatoda vasica, the leaves are used to treat stomach pains, fever, dehydration, diarrhea, dysentery, indigestion and gas troubles. The leaf paste of this plant has been reported for uses in the treatment of hoof rot in the literature [46]. Interestingly, aqueous extracts from the leaves have shown significant activity against Bacillus bacteria $[47,48]$.

\section{Amaranthaceae}

Paste prepared from whole plant of Amaranthus viridis is used here against weakness in cattle. The leaves of the same plant were reported as emollient in amenorrhea, scorpion sting and snake bite in a study conducted in Islamabad, Pakistan [49].

\section{Amaryllidaceae}

The crushed bulbs of Allium cepa are administered to treat indigestion, stomach gripe, fever and for lactation in the study area, whereas in Italy, they are used to prevent pestilence [50]. The leaves, flowers and bulb extracts of A. cepa have demonstrated activity against pathogens such as Staphylococcus aureus, Salmonella typhi, Candida albicans, and nematodes [48,51].

\section{Anacardiaceae}

The fruit pickle of Mangifera indica is used for mouth infections. Others have reported that the leaves of same plant are fed to livestock to treat retained fetal membrane [20]. Chloroform, ethanolic, water and petroleum ether extracts of $M$. indica were found to have antibacterial, anti-viral anti-fungal activities, as well as antiinflammatory properties $[52,53]$.

\section{Apiaceae}

Aerial parts of Foeniculum vulgare were used to treat indigestion and diarrhea. Flowers and fruit of the same species have been reported as galactagogues and ruminative [50]. Seeds of Trachyspermum ammi are given to cattle as appetite stimulant and to increase milk production. In the Sargodha district of Pakistan, seed powder and decoctions of the same plant were reported for treatments against genital prolapse and to treat retained fetal membrane [20]. Alcoholic and aqueous extracts of this plant species have shown antibacterial activity [54].

\section{Apocynaceae}

Leaves, stems and twigs of Calotropis procera are applied to cure mouth and eye watering, colic, indigestion, pain and inflammation. Other reports regarding use of this plant include crushed leaves for the relief of flatulence, latex to increase lactation and bark decoction for hoof rot [46]. The leaves and seeds are also reported to be useful for silent estrus and delayed puberty [20]. Alcoholic and aqueous extracts of $C$. procera have shown antibacterial activities [54]. Powder prepared from the roots and leaves of Carissa opaca is given to cattle to treat infected or sore throats and to heal wounds. In Uttar Pradesh, India, aerial parts of $C$. opaca were reported to be administered orally to kill pest in cattle [46].

\section{Araliaceae}

An aqueous extract of Hedera nepalensis is applied to remove leech in cattle. In Italy, the use of fresh leaves and plant decoctions for abortive and anti-inflammatory purposes have been reported [50].

\section{Asteraceae}

The seeds and paste made from the whole plant of Saussurea heteromalla are used to treat edema and to purify the blood. In Islamabad, the seeds were reported as carminatives and used also in tonics for horses and camels [49]. In the present study, we found that decoctions and pastes of Senecio chrysanthemoides are used for the treatment of sore joints and arthritis, whereas other work has reported the use of roots and leaves for treating blackleg disease and Evil-eye [55].

\section{Boraginaceae}

The leaf paste of Trichodesma indicum is used to treat stomach disorders and intestinal worms in cattle in the study area, whereas others have reported the use of this paste in the treatment of mastitis and for uterine prolapse [46].

\section{Brassicaceae}

Brassica campestris seed oil is used for skin, eye and stomach infections. Other studies in Pakistan and India $[20,46]$ have reported the use of this oil in topical applications for sores and the treatment of genital prolapses. Eruca sativa seed oil is used to treat dysentery in the study area. E. sativa seed powder has been reported for diarrhea in other work [46].

\section{Cannabaceae}

Paste from the leaves, seeds and floral buds of Cannabis sativa are applied as an appetite stimulant, anti-leech, anti-lice, and for abdominal swelling and indigestion. Other studies have reported the use of decoctions and 
infusions for measles and East coast fever [56] and leaves for genital prolapse [20].

\section{Convolvulaceae}

Paste prepared from Cuscuta reflexa is fed to cattle for treatment of swelling (rumination problems), indigestion and short mammary glands. Other studies have documented its use as a galactagogue food (after being fried) [57].

\section{Euphorbiaceae}

Seed oil of Ricinus communis is administered to treat constipation. Other studies have documented the use of $R$. communis for intestinal obstruction, hoof problems, digestive problems, wounds, abscesses, to expel retained placenta and for silent estrus/delayed puberty in cattle $[20,46,58]$. The stem/leaf hexane extract of $R$. communis was suggested to be active against Escherichia coli, Enterococcus faecalis, Pseudomonas aeruginosa and Staphylococcus aureus [59].

\section{Fabaceae}

Acacia nilotica bark decoctions are used for the treatment of stomach pains in livestock. The bark of this same plant has been reported to be used in the case of hoof rot and genital prolapse in cattle $[20,46]$. The seeds of Trigonella foenum-graecum are reported to treat diarrhea here, whereas in other areas of Pakistan they are used for treatment of genital prolapse, silent estrus and delayed puberty [20].

\section{Lythraceae}

The fruit rind of Punica granatum is used to cure dysentery. Other work reports the use of leaf paste for enteritis, bark powder for helminthic infection, flowers as a tonic and the rind as an astringent and to treat diarrhea [60]. Antibacterial studies on the alcoholic and aqueous extracts of this plant have demonstrated activity against Bacillus subtilis, Escherichia coli, Proteus vulgaris, Salmonella typhimurium, Pseudomonas aeruginosa and Staphylococcus aureus [51].

\section{Meliaceae}

The leaves and fruit of Melia azedarach are used against foot, mouth, skin infections, gas trouble and indigestion in the study areas while according to other studies; it is used as a cooling agent and for genital prolapse $[20,46]$.

\section{Ptderidaceae}

Adiantum incisum leaf paste is used for abdominal pain in the study area, whereas in Italy, a decoction of the plant is used to expel the placenta following delivery [50].

\section{Poaceae}

Paste prepared from the seeds of Oryza sativa is used to treat weakness and respiratory infection. It was reported $[20,50]$ that seeds of the same plant are also used against diarrhea and to treat retained fetal membrane. Triticum aestivum seeds are used against dysentery, sore mouth and to increase milk production in livestock. Other studies have reported its use as a ruminative, laxative, for dermatitis, delayed puberty, silent estrus and to treat retained fetal membrane [20,50]. Zea mays inflorescences are given to cure urinary inflammation in cattle. Z. mays has been reported for applications in wound healing and treating genital prolapse in other studies [20,50].

\section{Polygonaceae}

Local people use the roots and leaves of Rumex nepalensis for treating diarrhea, dysentery, intestinal worms, allergies and to stop bleeding in cattle. Crushed roots of this plant have been reported for treatment of blackleg disease (an infectious disease attributed to Clostridium spp.) [55].

\section{Rutaceae}

Citrus limon juice is used in the treatment of mastitis. Others have reported the use of citrus juice for uterine prolapse in cattle [20].

\section{Sapindaceae}

The powder and juice of Aesculus indica fruit and seeds is used against cough, fever, abdominal pain and to heal wounds in animals in the study area. However, in other regions of Pakistan, the seed endocarp is given to horses to relieve stomach pain, colic and swelling [61-63].

\section{Saxifragaceae}

Fresh leaves and powder derived from the rhizomes of Bergenia ciliata are topically applied for use in wound healing. Dried and fresh leaves of the same plant have been used to treat diarrhea in animals [64]. Alcoholic and aqueous extracts of $B$. ciliata rhizome has shown antibacterial and antifungal activities [65].

\section{Scrophulariaceae}

The fresh leaf paste of Verbascum thapsus is used to treat diarrhea. Others report the use of a leaf ointment for the treatment of rectal prolapse [50].

\section{Solanaceae}

Solanum surattense is used for healing wounds, fever, indigestion, cough and as a tonic. Others have reported the use of the leaves for genital prolapse [20]. A leaf extracts of $S$. surattense was found to be active against Staphylococcus aureus, Salmonella typhi, Candida albicans and nematodes [48,51]. The root paste of Withania somnifera is topically applied to treat bovine mastitis in 
Table 2 Informant consensus values based on categories of veterinary conditions

\begin{tabular}{|c|c|c|c|}
\hline Category & Botanical taxa used & Plant reports & ICF value \\
\hline Gastrointestinal disorders (incl. tympany, colics) & 47 & 70 & 0.33 \\
\hline Skin diseases (incl. wounds and diseases affecting eye, ear, and throat) & 30 & 54 & 0.45 \\
\hline Diseases related to milk production & 4 & 7 & 0.50 \\
\hline Rheumatoid disorders and inflammations & 3 & 5 & 0.50 \\
\hline Worms and other parasitic diseases & 14 & 35 & 0.62 \\
\hline Reproductive disorders & 9 & 24 & 0.63 \\
\hline Respiratory disorders (cold, cough) and fever & 10 & 29 & 0.68 \\
\hline
\end{tabular}

this study area, whereas the crushed roots of this same species are used against an evil spirit (Wan laffa) in animals in Ethiopia [55]. Alcoholic and aqueous extracts of W. somnifera have shown antibacterial activity against $\mathrm{Ba}$ cillus subtilis, Escherichia coli, Proteus vulgaris, Salmonella typhimurium, Pseudomonas aeruginosa and Staphylococcus auerus, as well diuretic and anti-hypercholesterolemic activities [48,54].

\section{Theaceae}

Decoctions of Camellia sinensis leaves are used to cure fever in cattle in this region, while another study in Sargodha district (Pakistan) reported the use of this decoction for treating retained fetal membrane in cows [20]. Fermented tea has been shown to be hypolipidemic and to reduce high blood pressure [49].

\section{Xanthorrhoeaceae}

The leaf pulp of Aloe vera is administered orally as ruminative. The pulp of this same species has also been reported for similar use in the treatment of digestive problems [58]. Alcoholic and aqueous extracts of this plant have shown significant activity against Bacillus subtilis, Escherichia coli, Proteus vulgaris, Salmonella typhimurium, Pseudomonas aeruginosa and Staphylococcus aureus [54,66,67]. Leaves of Asphodelus tenuifolius were used to cure weakness in horses in our study, while others have reported that root paste of this plant is applied to wounds in cattle [46].

\section{Zingiberaceae}

Turmeric powder (from Curcuma longa rhizomes) is topically applied for wound healing in cattle in the study area, while a study on equine medicines has mentioned that roots of this plant are used for hoof problems and

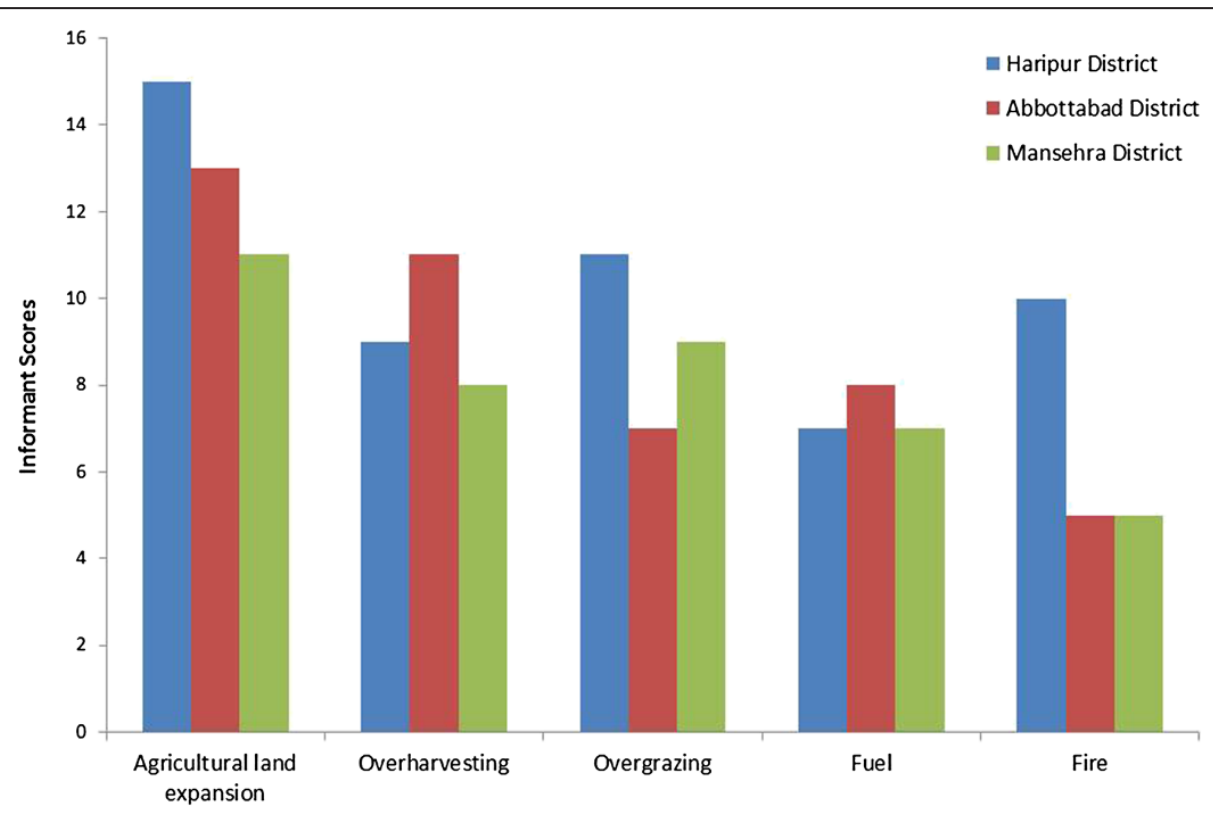

Figure 3 Factors perceived to be threats to the local medicinal flora. Ranking based on interviews from the three districts included in this study. 
sore joints [58]. Alcoholic and aqueous extracts of $C$. longa have shown antibacterial activity [54]. Chloroform, ethanol, water and petroleum ether extracts of C. longa rhizome were also found to be active against bacteria, viruses, and fungi, and have shown anti-inflammatory activities [52,53].

\section{Cultural importance of the species}

The Cultural Importance index (CI) of species is useful for estimating the significance of certain plants to a given culture [68] and takes into account not only the spread of the use (number of informants) for each species, but also its versatility, i.e. the diversity of its uses [68].

Based on medicinal applications, Trachyspermum ammi was found to be the most cited species followed by Curcuma longa, Melia azedarach, Zanthoxylum armatum var. armatum, Adhatoda vasica, Allium cepa, Foeniculum vulgare, Prunus persica, Punica granatum, Trichodesma indicum, Berberis lycium, Triticum aestivum and Peganum harmala (Table 1). It is notable that the top ten species of medicinal plants used to treat various livestock conditions were cited in all three major study sites (Haripur, Abbottabad, and Mansehra).

\section{Cultural importance of the families}

With regards to the diversity of species used, Fabaceae and Poaceae were the most important, with 6 species cited. Like the study by Pardo-de-Santayana et al. [30], we also elected to add the sum of CI of species in each family in order to measure the mean cultural importance of the families (mCIf). Unlike the aforementioned study, however, the number of species reported here did not strongly correlate with the number of species $\left(R^{2}=0.211\right)$. This could be explained, perhaps, by the greater diversity of families (with a more limited number of species per family, average of 1.9 species/family) quoted for ethnoveterinary applications. Of the families reported, Apiaceae had the highest $\mathrm{mCIf}$ value, despite having only three species in this group (Figure 2).

\section{Informant consensus}

Perceived efficacy of medicinal plants can be assessed by ICF values, with those plants that are supposed to be effective in curing diseases having elevated ICF levels [69]. We identified seven major disease categories and the highest ICF values were recorded for respiratory disorders and fever (0.68), followed by reproductive disorders (0.63), worms and other parasitic diseases (0.63) (Table 2).

\section{Comparison with human medicine}

A large number of the veterinary plant reports share commonalities with the folk medical practices used in traditional ethnomedicine for humans in surrounding sites (last column in Table 1). This overlap may be a reflection on how folk veterinary remedies may be the diachronic result of a deep observation of the efficacy of certain plants used in animal diseases or at least of intense transfers of local knowledge between the folk veterinary and the ethnomedical domains.

\section{Bio-conservation concerns}

Various human activities may be implicated in placing some of the local medicinal flora under a state of threat within their natural habitat. The perceptions that local people share regarding this phenomenon of threats to local ecological resources - medicinal plants, in particular, was examined based on interviews with 15 key respondents in study districts. We examined these perceived threats using pair-wise ranking [29] of five central factors: agricultural land expansion, over-harvesting, over-grazing, uncontrolled fire setting and fuel wood collection. It was observed that agricultural land expansion was perceived as the dominant threat to medicinal plants used in ethnoveterinary medicine, followed by over-harvesting, overgrazing, fire and fuel wood collection (Figure 3). Current conservation efforts concerning medicinal plants in this region are very limited, and as a result, the majority of them have no protection. This a major issue to be considered in future research and in local rural development initiatives.

\section{Conclusions}

A remarkable heritage of folk veterinary knowledge has been preserved within the framework of local knowledge and practices in the Pakistani communities of the Lesser Himalayas. However, like many other studies in this discipline have found, local knowledge is fragile and susceptible to rapid erosion with the expansion of biomedical paradigms and replacement of traditional resources with modern allopathic medicines. This is increasingly the case in both human and veterinary medicine. Nevertheless, as the majority of the reported species are wild and sometimes rare or under threat, much heed must be taken not to diminish these plant populations.

It is more urgent now than ever to record this rich body of knowledge not only for the purpose of biocultural conservation, but also to provide insights to scientists engaged in the search for new herbal veterinary therapies and especially to local stakeholders, who work on fostering endogenous trajectories of communitybased rural development projects in mountainous areas. The latter perspective is of crucial importance in the possible implementation of ethnobiological studies in disadvantaged areas, such as the mountain regions of Pakistan [70-73] as it may have a tremendous impact in sustaining and/or revitalizing communal forms of natural resource management [74]. Moreover, emic visions of environmental protection and provision of health and dietary care both for humans and animals may represent 
the key to environmental and social sustainability of social-ecological systems [75]. The validation and eventual application of this knowledge into concrete, comprehensive and culturally appropriate participatory initiatives aimed at fostering the sustainable use of local natural resources would promote the well-being of both animals and local communities.

\section{Competing interest}

Authors declare that they have no competing interest.

\section{Authors' contributions}

AMA conducted the ethnobotanical survey and drafted the manuscript; SMK helped in the data compilation; MA supported the field data collection; MAK supervised the project and helped in plant identification; CLQ analyzed the data and reviewed the manuscript; AP critically reviewed the manuscript and wrote the discussion and the conclusions. All authors read and approved the final manuscript.

\section{Acknowledgement}

We are grateful to all the study participants and the local communities for having shared their valuable traditional knowledge.

\section{Author details}

'Department of Environmental Sciences, COMSATS Institute of Information Technology, Abbottabad 22060, Pakistan. ${ }^{2}$ Department of Botany, Hazara University Mansehra, Mansehra 21300, Pakistan. ${ }^{3}$ Department of Plant Sciences, Quaid-i-Azam University, Islamabad 45320, Pakistan. ${ }^{4}$ Department of Dermatology, Emory University School of Medicine, 1518 Clifton Rd NE, CNR Bldg. 5000, Atlanta, GA 30322, USA. ${ }^{5}$ Center for the Study of Human Health, Emory College of Arts and Sciences, 550 Asbury Circle, Candler Library 107, Atlanta, GA 30322, USA. ${ }^{6}$ University of Gastronomic Sciences, Piazza Vittorio Emanuele 9, Pollenzo I-12042 Bra/Pollenzo, Italy.

Received: 21 March 2013 Accepted: 5 December 2013

Published: 20 December 2013

\section{References}

1. McCorkle CM: An introduction to ethnoveterinary research and development. J Ethnobio/ 1986, 6:129-149.

2. Katerere DR, Luseba D: Ethnoveterinary botanical medicine. Herbal medicines for animal health. Boca Raton: CRC Press; 2010.

3. Eswaran S, Boomibalagan P, Rathinavel S: Ethnoveterinary medicinal practices of the villagers of Usilampatti Taluk of Madurai district, India. Int J Bot 2013, 9:37-43.

4. Galav P, Jain A, Katewa SS: Ethnoveterinary medicines used by tribals of Tadgarh-Raoli wildlife sanctuary, Rajasthan, India. Indian J Tradit Knowl 2013, 12:56-61.

5. Mishra D: Cattle wounds and ethnoveterinary medicine: a study in Polasara block, Ganjam district, Orissa, India. Indian J Tradit Knowl 2013, 12:62-65.

6. Mallik BK, Panda T, Padhy RN: Ethnoveterinary practices of aborigine tribes in Odisha, India. Asian Pacific Journal of Tropical Biomedicine 2012, 2:S1520-S1525.

7. Pragada PM, Rao GMN: Ethnoveterinary medicinal practices in tribal regions of Andhra Pradesh, India. Bangladesh Journal of Plant Taxonomy 2012, 19:7-16.

8. Bharati KA, Sharma BL: Plants used as ethnoveterinary medicines in Sikkim Himalayas. Ethnobot Res Appl 2012, 10:339-356.

9. Sharma R, Manhas RK, Magotra R: Ethnoveterinary remedies of diseases among milk yielding animals in Kathua, Jammu and Kashmir, India. J Ethnopharmacol 2012, 141:265-272.

10. Naik RM, Venugopalan V, Kumaravelayutham P, Krishnamurthy YL: Ethnoveterinary uses of medicinal plants among the Lambani community in Chitradurga district, Karnataka, India. Asian Pacific Journal of Tropical Biomedicine 2012, 2:S470-5476.

11. Mishra D: Ethnoveterinary practices and use of herbal medicines for treatment of skin diseases in cattle: a study in Polsara Block, Ganjam District, Orissa, India. Veterinary World 2011, 4:250-253.
12. Phondani PC, Maikhuri RK, Kala CP: Ethnoveterinary uses of medicinal plants among traditional herbal healers in Alaknanda catchment of Uttarakhand, India. Afr J Tradit Complement Altern Med 2010, 7:195-206.

13. Rajput DS, Tripathi H, Bhanja SK: Ethnoveterinay practices of Raika pastoralists for camel health management in Bikaner District of Rajasthan. Asian Agri-History 2005, 9:243-252.

14. Sikarwar RLS, Kumar V: Ethnoveterinary knowledge and practices prevalent among the tribals of central India. Journal of Natural Remedies 2005, 5:147-152.

15. Sharma UK, Sapcota D: Studies on some ethnoveterinary practices on Dhemaji district of Assam. Journal of Natural Remedies 2003, 3:73-77.

16. Maiti S, Chakravarty P, Garai S, Bandyopadhyay S, Chouhan VS: Ethno-veterinary practices for ephemeral fever of Yak: a participatory assessment by the Monpa tribe of Arunachal Pradesh. Indian J Tradit Knowl 2013, 12:36-39.

17. Selvaraju A, Ayyanar M, Rathinakumar SS, Sekar T: Plants used in ethno-veterinary medicine by malayali tribals in Salem district of Tamil Nadu, India. Medicinal Plants 2011, 3:209-215.

18. Raziq A, de Verdier K, Younas M: Ethnoveterinary treatments by dromedary camel herders in the Suleiman mountainous region in Pakistan: an observation and questionnaire study. J Ethnobiol Ethnomed 2010, 6:16

19. Hussain A, Khan MN, Iabal Z, Sajid MS: An account of the botanical anthelmintics used in traditional veterinary practices in Sahiwal district of Punjab, Pakistan. J Ethnopharmacol 2008, 119:185-190.

20. Dilshad SMR, Rehman N, Iqbal Z, Muhammad G, Iqbal A, Ahmed N: An inventory of the ethnoveterinary practices for reproductive disorders in cattle and buffaloes, Sargodha district of Pakistan. J Ethnopharmacol 2008, 117:393-402

21. Dilshad SMR, Rehman NU, Ahmad N, labal A: Documentation of ethnoveterinary practices for mastitis in dairy animals in Pakistan. Pakistan Vet J 2010, 30:167-171.

22. Farooq Z, lqbal Z, Mushtaq S, Muhammad G, lqbal MZ, Arshad M: Ethnoveterinary practices for the treatment of parasitic diseases in livestock in Cholistan desert (Pakistan). J Ethnopharmacol 2008, 118:213-219.

23. Sindhu ZUD, Iqbal Z, Khan MN, Jonsson NN, Siddique M: Documentation of ethnoveterinary practices used for treatment of different ailments in a selected hilly area of Pakistan. Int J Agric Biol 2010, 12:353-358.

24. Muhammad $\mathrm{G}$, Khan $\mathrm{MZ}$, Hussain $\mathrm{MH}$, Iqbal Z, Iqbal M, Athar M: Ethnoveterinary practices of owners of pneumatic-cart pulling camels in Faisalabad City (Pakistan). J Ethnopharmacol 2005, 97:241-246.

25. Statistical Division, Government of Pakistan: Livestock Population in Pakistan Lahore: Agricultural Census Organization; 2006.

26. Ali SI, Qaiser M: Flora of Pakistan. Karachi-Pakistan: Botany Department, University of Karachi; 1995-2005.

27. The Plant List. http: //www.theplantlist.org.

28. Stevens PF: Angiosperm Phylogeny Website. Version 12. 2. http://www. mobot.org/MOBOT/research/APweb.

29. Balemie K, Kebebew F: Ethnobotanical study of wild edible plants in Derashe and Kucha Districts, South Ethiopia. J Ethnobiol Ethnomed 2006, 2:53.

30. Pardo-de-Santayana M, Tardío J, Blanco E, Carvalho AM, Lastra JJ, San Miguel E, Morales R: Traditional knowledge of wild edible plants used in the northwest of the Iberian Peninsula (Spain and Portugal): a comparative study. J Ethnobiol Ethnomed 2007, 3:27.

31. Tardío J, Pardo-de-Santayana M: Cultural importance indices: a comparative analysis based on the useful wild plants of Southern Cantabria (Northern Spain). Economic Botany 2008, 62:24-39.

32. Heinrich M, Ankli A, Frei B, Weimann C, Sticher O: Medicinal plants in Mexico: Healers' consensus and cultural importance. Soc Sci Med 1998, 47:1859-1871

33. Ashok A, Reddy PG: Some reports on traditional ethno-veterinary practices from Savargaon areas of Ashti Taluka in Beed district (M.S.) India. International Journal of Advanced Biological Research 2012, 2:115-119.

34. Gaur RD, Sharma J, Painuli RM: Plants used in traditional health care of livestock by Gujjar community of Sub-Himalayan Tract, Uttarakhand, India. Indian Journal of Traditional Knowledge 2010, 1:243-248.

35. Islam M, Anwar Z, Tabassum S, Khan SA, Zeb AC, Abrar M, Khattak KU, Khattak JZK: Plants of Ethno-Veterinary Uses of Tunglai Mountain Baffa Mansehra, Pakistan. International Journal of Animal and veterinary Advances 2012, 4:221-224. 
36. Khan MA, Khan MA, Hussain M: Ethnoveterinary medicinal uses of plants of Poonch valley Azad Kashmir. Pakistan Journal of Weed Sciences 2012, 18:495-507.

37. Mondal T: An investigation on ethno-veterinary medicinal plants of Siliguri Subdivision of Darjeeling district, West Bengal, India. Journal of Today's Biological Sciences 2012, 1:45-50

38. Pande PC, Tiwari L, Pande HC: Ethnoveterinary plants of Uttranchal - a review. Indian Journal of Traditional Knowledge 2007, 6:444-458.

39. Pandit PK: Inventory of ethno veterinary medicinal plants of Ghargram division, West Bangal, India. Indian Forester 2010, 136:1183-1194.

40. Phondani PC, Maikhuri K, Kala P: Ethno veterinary uses of medicinal plants among traditional herbal Healers in Alaknanda catchment of Uttarakhand, India. African Journal of Traditional and Complementary Medicines 2010, 7:195-206.

41. Shah GM, Ahmad M, Arshad M, Khan MA, Zafar M, Sultana S: Ethno-phyto-veterinary medicines in northern Pakistan. The Journal of Animal and Plant Sciences 2012, 22:791-797.

42. Shah $R$, Pande PC, Tiwari L: Traditional veterinary herbals medicines of western part of Almora district, Uttarakhand, Himalayas. Indian Journal of Traditional Knowledge 2008, 7:355-359.

43. Singh $P$, Singh BK, Joshi GC, Lalit M: Veterinary Ethno-Medicinal Plants in Uttarakhand Himalayan Region Tewari. Nature and Science 2009, 7:44-52.

44. Singh PK, Singh S, Kumar V, Krishna B: Ethno veterinary healthcare practices in Marihan sub-division of district Mirzapur, Uttar Pradesh, India. Life Sciences Leaflets 2011, 16:561-569.

45. Tiwari $L$, Pande PC: Ethno veterinary medicines in Indian perspective: reference to Uttarkhand, Himalaya. Indian Journal of Traditional Knowledge 2010, 9:611-617.

46. Ali ZA: Folk veterinary medicine in Moradabad district Uttar Pradesh, India. Fitoterapia 1999, 70:340-347.

47. Parsad G, Panday S, Gupta KK: Antimicrobial activity of certain indigenous drugs and drug plants against certain bacterial species. Hamdard Medicus 1999, 27:53-57.

48. Srinivasan D, Nathan S, Suresh T, Perumalsamy PL: Antimicrobial activity of certain Indian medicinal plants used in folklore medicine. J Ethnopharmacol 2001, 74:217-220.

49. Shinwari MI, Khan MA: Folk use of medicinal herbs of Margalla hills national park, Islamabad. J Ethnopharmacol 2000, 69:45-56.

50. Uncini Manganelli RE, Camangi F, Tomei PE: Curing animals with plants, traditional usage in Tuscany, Italy. I Ethnopharmacol 2001, 78:171-191.

51. Qarar F, Kalhora MA, Badar Y: Antihelmintic properties of some indigenous plants. Hamdard Medicus 1998, 21:115-117.

52. Grewal RC: Medicinal Plants. New Delihi: Campus Books International; 2000.

53. Khattak S, Rehman S, Shah HU, Ahmed W, Ahmed M: Biological effects of indigenous medicinal plants Curcuma longa and Alpinia galangal. Fitoterapia 2005, 76:254-257.

54. Ahmad I, Mehmood Z, Mohammad F: Screening of some Indian medicinal plants for their antimicrobial properties. J Ethnopharmacol 1998, 62:183-193.

55. Yineger $H$, Kelbessa E, Bekele T, Lulekal E: Ethno veterinary medicinal plants at Bale Mountains National Park, Ethiopia. Journal of Ethnopharmacology 2007, 112:55-70.

56. Tabuti JR, Dhillion SS, Lye KA: Ethno veterinary medicine for cattle (Bosindicus) in Bulamogi County, Uganda. Journal of Ethnopharmacology 2003, 88:279-286.

57. Bandyopadhyay S, Mukherjee SK: Ethno veterinary medicine from Koch Bihar district, West Bengal. Indian Journal of Traditional Knowledge 2005, 4(4):456-461.

58. Lans C, Turner N, Khan T, Brauer G, Lourenco G, Georges K: Ethnoveterinary medicines used for horses in Trinidad and in British Columbia, Canada. J Ethnobiol Ethnomed 2006, 2:31.

59. McGaw $\sqcup$, Merwe DVD, Eloff JN: In vitro anthelmintic, antibacterial and cytotoxic effects of extracts from plants used in South African ethno veterinary medicine. The Veterinary Journal 2007, 173:366-372.

60. Karthickeyan SMK, Gajendran K: Indigenous technical know-how in the health care of domestic animals. Indian Journal of Traditional Knowledge 2005, 4(4):462-463

61. Abbasi AM, Khan MA, Ahmad M, Zafar M: Medicinal plant biodiversity of Lesser Himalayas, Pakistan. New York: Springer; 2012.

62. Shah GM, Khan MA: Common medicinal folk recipes of Siran Valley, Mansehra, Pakistan. Ethobotanical Leaflet 2006, 4:110-130.
63. Matin A, Khan MA, Ashraf M, Qureshi RA: Traditional uses of shrubs and trees of Himalayan Region, Shogran valley, District Mansehra, Pakistan. Hamdard Medicus 2002, 45:50-56

64. Shinwari ZK, Gilani SS: Sustainable harvest of medicinal plants at Bulashbar Nullah, Astore (Northern Pakistan). J Ethnopharmacol 2003, 84:289-298.

65. Gorsi MS: Antimicrobial activity of some medicinal plants of Muzaffarabad. Hamdard Medicus 2005, 48:27-41.

66. Sweelam ME: The potential use of some ornamental plants for nematodal control in Egypt. Bulletin Agriculture University Cairo 1989, 40:391-393.

67. Trivedi PC: Medicinal plants. Jodhpur (India) Agrobios: Ethnobotanical Approaches; 2006

68. Albuquerque UP, Andrade LHC, Silva ACO: Use of plant resources in a seasonal dry forest (Northeastern Brazil). Acta Botanica Brasilica 2005, 19:27-38.

69. Teklehaymanot T, Giday M: Ethnobotanical study of medicinal plants used by people in Zegie Peninsula. Northwestern Ethiopia. J Ethnobiol Ethnomed 2007, 3:12

70. Akhtar N, Rashid A, Murad W, Bergmeier E: Diversity and use of ethno-medicinal plants in the region of Swat, North Pakistan. J Ethnobiol Ethnomed 2013, 9:25.

71. Khan SM, Page S, Ahmad H, Shaheen H, Ullah Z, Ahmad M, Harper DM: Medicinal flora and ethnoecological knowledge in the Naran Valley, Western Himalaya, Pakistan. J Ethnobiol Ethnomed 2013, 9:4.

72. Abbasi AM, Khan MA, Shah MH, Shah MM, Pervez A, Ahmad M: Ethnobotanical appraisal and cultural values of medicinally important wild edible vegetables of Lesser Himalayas-Pakistan. J Ethnobiol Ethnomed 2013, 9:66

73. Rotherham ID: Cultural Severance and the Environment. The Ending of Traditional and Customary Practice on Commons and Landscapes Managed in Common. Dordrecht/Heidelberg/New York/London: Springer; 2013.

74. Pieroni A, Nedelcheva A, Hajdari A, Mustafa B, Scaltriti B, Cianfaglione K, Quave CL: Local Knowledge on Plants and Domestic Remedies in the Mountain Villages of Peshkopia (Eastern Albania). Journal of Mountain Science 2014, 11:180-194

75. Berkes F, Colding J, Folke C: Navigating Social-Ecological Systems. Building Resilience for Complexity and Change. Cambridge: Cambridge University Press; 2003.

doi:10.1186/1746-4269-9-84

Cite this article as: Abbasi et al.: Botanical ethnoveterinary therapies in three districts of the Lesser Himalayas of Pakistan. Journal of Ethnobiology and Ethnomedicine 2013 9:84.

\section{Submit your next manuscript to BioMed Central and take full advantage of:}

- Convenient online submission

- Thorough peer review

- No space constraints or color figure charges

- Immediate publication on acceptance

- Inclusion in PubMed, CAS, Scopus and Google Scholar

- Research which is freely available for redistribution 